\title{
Pelatihan Pelaksanaan Strategi Membaca Read Aloud oleh Guru TK Witri I Kota Bengkulu
}

\author{
Didik Suryadi $^{1}$, Melia Eka Daryati ${ }^{2}$, Indrawati ${ }^{3}$ \\ ${ }^{1,2,3}$ PG PAUD FKIP Universitas Bengkulu \\ 1.didiksuryadi@unib.ac.id \\ ${ }^{2}$ melia eka@unib.ac.id \\ 3indrawati@unib.ac.id
}

\begin{abstract}
ABSTRAK
Salah satu ketrampilan yang memberikan kemampuan masyarakat untuk bertahan hidup pada era abad 21 adalah ketrampilan literasi membaca yang tercermin dalam kemampuan dan kemauan membaca. Hasil kajian teoritis dan praktis menunjukkan bahwa strategi Read Aloud merupakan strategi yang efektif untuk menstimulasi tumbuh kembangnya kedua kebutuhan tersebut. Di pihak lain pengetahuan dan kemampuan melaksanakan Read Aloud masih belum memadahi. Hal ini terlihat dari masih rendahnya nilai pre-test pengetahuan (34\%) dan praktek $(51 \%)$. Kegiatan pengabdian pada masyarakat ini ditujukan untuk meningkatkan pemahaman dan ketrampilan guru terhadap strategi tersebut. Mitra pengabdian adalah guru TK Witri 1 Kota Bengkulu. Metode yang dipakai adalah workshop yang terbagi kedalam tiga kegiatan, yaitu ceramah dan diskusi, peer teaching, dan praktek langsung di kelas riil. Hasilnya adalah 85 \% guru mitra menyatakan Read Aloud sebagai strategi baru dalam pembelajaran membaca di TK. Semua guru mitra mencapai penguasaan materi pengetahuan yang diharapkan yaitu $\geq 75$ dan semua guru mitra mencapai tingkat ketrampilan yang diharapkan dalam menerapkan strategi Read Aloud yaitu dalam tingkat ketuntasan $\geq 75 \%$. Implementasi Read Aloud sebagai strategi pembelajaran membaca pada anak usia dini di TK secara konsisten akan berkontribusi secara signifikan terhadap tumbuh kembangnya kemampuan dan kemauan membaca anak di masa depan, serta menstimulasi aspek perkembangan lainnya terutama kognitif, dan sosial emosioal anak.
\end{abstract}

Kata Kunci : Strategi membaca, Read Aloud, PAUD

\section{ABSTRACT}

One of the skills enabling people to survive in the 21st century is reading skill reflected in the ability and willingness to read. The results of theoretical and practical studies showed that the Read Aloud strategy was an effective strategy to stimulate the growth and development of that skill. On the other side, the teachers' knowledge and skills about Read Aloud has not been sufficient yet. This community service activity was aimed to increase teachers' understanding and skills of this strategy. The community service partners were kindergarten teachers of Witri 1, Bengkulu City. The method used was a workshop which was divided into three activities, namely lectures and discussions, peer teaching, and direct practice in real class rooms. The result indicated $85 \%$ of the teachers stated that Read Aloud was a fresh strategy in teaching reading in kindergarten. All of the teachers passed the expected grade of mastering the content in the grade of $\geq 75$ and all of the teachers passed expected grade in implementing the Read Aloud strategy in the grade of $\geq 75$. A consistent implementation of Read Aloud as a strategy for learning to read in kindergarten will contribute significantly to the development of children's reading skills in the future, and stimulate other aspects of development, especially cognitive and social emotional of children.

Keywords : Reading teaching strategy, Read Aloud, Early Childhood Education

\section{PENDAHULUAN}

Salah satu ketrampilan yang memberikan kemampuan masyarakat untuk bertahan hidup pada era abad 21 adalah ketrampilan literasi membaca dan menulis (Atmazaki et al., 2017).
Oleh karena itu, anak-anak sejak usia dini hendaknya sudah disiapkan untuk menguasai ketrampilan literasi membaca dan menulis. Di pihak lain, kemampuan dan minat baca masyarakat masih rendah. Hal tersebut terlihat 
dari hasil beberapa survei internasional seperti yang dilakukan oleh PIRLS, juga oleh PISA. Studi PIRLS pada tahun 2006 menunjukkan nilai kemamampuan membaca 407 , dan pada tahun 2011 nilainya 428. Nilai tersebut masih jauh dibahwa nilai pusat yang ditetapkan yaitu 500. Hasil studi PISA menunjukkan gejala yang sama. Tahun 2000 capaian literasi membaca siswa Indonesia masih sangat rendah, yaitu menduduki peringkat ke 39 dari 42 negara yang disurvei, dengan nilai rata-rata 371 . Nilai ratarata tertinggi adalah 546 dicapai oleh siswa Finlandia (Hayat \& Yusuf, 2015), Hasil survei PISA tahun 2012 skor membaca anak indonesia adalah 396 dan 397 pada tahun 2015 (Atmazaki et al., 2017). Uraian di atas tampak jelas bahwa di satu pihak terdapat kebutuhan membekali masyarakat dengan kemampuan dan budaya literasi baca untuk mengantisipasi tuntutan kehidupan di abad 21, di pihak lain kemampuan dan kemauan memmbaca anak-anak Indonesia masih belum memadahi.

Upaya peningkatan kemampuan dan kemauan membaca sesungguhnya telah dilakukan baik oleh pemerintah maupun masyarakat. Salah satu upaya tersebut adalah pengadaan buku-buku baik di perpustakaan umum maupun di sekolah sekolah.

Hasil pengalaman kunjungan ke berbagai Taman Kanak-Kanak (TK) selama ini menunjukan bahwa tiap-tiap TK telah memiliki buku-buku bacaan, walaupun jumlah dan kualitasnya bervariasi. Ada beberapa TK yang memiliki koleksi buku lebih banyak dan lebih baik kondisinya, tetapi ada beberapa yang memiliki koleksi dalam jumlah dan kondisi kurang memadahi. Hal yang sangat penting dari dialog dengan guru dan kepala sekolah tentang pemanfaatan buku tersebut bahwa buku-buku bacaan yang ada belum dimanfaatkan secara maksimal. Salah satu indikasinya adalah ketika ditanyakan kepada guru atau kepala sekolah TK tentang judul buku yang pernah dibacakan kepada anak pada 1 minggu terakhir maka jawabannya mereka tidak bisa menyebutkan. Jawaban serupa ketika pertanyaan yang sama diajukan kepada guru/kepala sekolah TK peserta Program Pendidikan Profesi Guru PAUD. Kondisi tersebut memberikan gambaran bahwa kegiatan membacakan buku bacaan di TK sasaran dan di berbgai TK lain belum dilakukan secara intensif.

Terdapat berbagai hal yang menjadi penyebabnya. Pertama, adanya kecenderungan para guru lebih menekankan kepada pembelajaran membaca dengan pendekatan fonik. Harapannya anak-anak memiliki kemampuan decoding yang lebih baik. Konsep pembelajaran membaca adalah penguasaan kemampuan decoding sebagai modal awal yang harus dikuasai oleh anak sebelum mereka berinteraksi dengan buku-buku bacaan. Hal ini berakibat pada suasana pembelajaran menjadi mekanistis. Kedua, para guru belum memahami pentingnya peran kegiatan membacakan secara nyaring (reading aloud) bagi perkembangan kemampuan dan kemauan membaca anak. Trelease menukil dua temuan penting dari hasil analisa Komisi Membaca Departemen Pendidikan Amerika Serikat terhadap ratusan penelitian bahwa pertama, Read Aloud merupakan satu-satunya kegiatan penting yang harus dilakukan agar anak sukses membaca dan kedua, Read Aloud tidak hanya penting dilakukan di rumah tetapi juga di dalam kelas. Kemungkinan ketiga, para guru memang belum memiliki pemahaman memadahi cara menerapkan Read Aloud di kelas mereka (Trelesase, 2017) .

Berdasar pada latar belakang di atas kegiatan pengabdian pada masyarakat ini dilaksanakan untuk meningkatkan pemahaman dan kemampuan guru TK menerapaan Read Aloud sebagai bagian integral dalam pembelajar di sekolah untuk memanfaat buku-buku bacaan yang tersedia di sekolah secara intensif.

Strategi Read Aloud dipilih berlandas berbagai hasil penelitian yang menjukkan dampak positif strategi ini dalam pengembangan kemampuan dan kemauan membaca anak. (Duursma, Augustyn, \& Zuckerman, 2008) merangkum berbagai hasil penelitian tetang pentingnya kegiatan Read Aloud bagi perkembangan bahasa anak. Membacakan buku kepada anak sejak usia pra sekolah membantu perkembangan bahasa dan literasi anak yang pada gilirannya membantu kesiapan anak memasuki sekolah. Read Aloud dapat mengembangkan kemampuan yang diperlukan untuk melakukan decoding, juga untuk meningkatkan motivasi membaca anak (Ledger \& Merga, 2018) dan (Morrow, Rand, \& Smith, 1995). Read Aloud tidak hanya berkontribusi terhadap peningkatan penguasaan anak terhadap unsur yang dibutuhkan untuk menguasai kemampuan membaca, tetapi juga terbukti guru dan siswa menyenangi kegiatan tersebut (Sajid, Kassim, \& Hasan, 2019) Penelitian Rahimah, Rukayah dan Hadiyah menyimpulkan bahwa Read Aloud terbukti dapat meningkatkan kemampuan membaca awal anak TK (Rahimah, Rukayah, \& Hadiyah, 2014). 


\section{METODE KEGIATAN}

Objek kegiatan pengabdian adalah pengetahuan dan ketrampilan guru TK tentang strategi Read Aloud untuk mengoptimalkan pemanfaatan buku bacaan sebagai strategi dalam pembelajaran membaca. Pelaksanaan kegiatan dilakukan di sekolah TK Witri 1, Kota Bengkulu. Subjek kegiatan adalah para guru TK Witri 1 Kota Bengkulu yang berjumlah 13 orang. Metode kegiatan berupa workshop yang terbagi kedalam tiga kegiatan, yaitu ceramah dan diskusi berbasis kajian literatur untuk memberikan pemahaman tentang strategi Read Aloud. Hal demikian akan memberikan manfaat penambahan wawasan pengetahuan bagi guru tentang strategi pembelajaran yang dapat diterapkan di TK. Kedua, adalah simulasi penerapan strategi Read Aloud dalam bentuk peer teaching, dan ketiga adalah implementasi di kelas riil.

\section{HASIL \& PEMBAHASAN}

Hasil kegiatan dapat digolongkan kedalam 2 hal, pertama adalah pengetahuan dan kedua adalah tingkat ketrampilan dalam melaksanakan strategi Read Aloud. Pengetahuan guru mitra terhadap strategi ini adalah masih sangat kurang. Hampir semua guru mitra belum mengetahui muatan dari tiap aspek dalam pelaksanaan Read Aloud. Hal yang diketahui adalah pengertian Read Aloud sebagai kegiatan membaca nyaring oleh anak. Artinya, Read Aloud dipandang sebagai aktivitas anak membaca secara nyaring. Hal demikian tidak sesuai dengan pengertian Read Aloud seperti yang seharusnya. Para ahli (Harjanty, 2019), (Mascareño, Deunk, Snow, \& Bosker, 2017), (Kumar, 2015) yang berpendepat bahwa pengertian Read Aloud sebagai strategi memiliki beberapa ciri. Pertama, guru membacakan secara bersuara sehingga di dengar oleh anak, bukan menceritakan isi buku atau mendongengkan isi buku. Kedua, pembacaan di lakukan secara ekspresif baik gestur maupun suaranya. Ketiga, adanya keaktifkan dialog atau percakapan antara anak dengan guru pada saat proses pembacaan. Dialog tersebut dapat berupa pertanyaan, komentar atau penilaian siswa terhadap tokoh maupun kejadian atau seting cerita. Keempat, kegiatan pembacaan dilakukan oleh guru kepada anak

Demikian juga ketika merespon pertanyaan tentang unsur yang ada dalam pelaksanaan strategi Read Aloud, seluruh mitra belum dapat menjelaskan unsur tersbut. Mc.Gee dan Schickedanz menjabarkan tiga unsur yang ada dalam strategi Read Aloud (McGee \& Schickedanz, 2007). Unsur pertama adalah pengenalan buku. Pada kegiatan pengenalan buku guru mengenalkan judul buku, illustrator, mengenalkan ilustrasi pada sampul buku serta memprediski isi buku berdasar pada judul dan ilustrasi sampul buku. Unsur kedua merupakan kegiatan membacakan buku. Terdapat beberapa kegiatan dalam unsur kedua ini, yaitu mengenalkan paling sedikit 5 kosa kata baru atau penting, menggunakan intonasi sura yang ekspresif, menyertai dengan gestur yang sesuai, memberikan komentar tentang perasaan atau pikiran tokoh, serta merespon tanggapan siswa terhadap tokoh dengan cara memberikan pertanyaan kritis. Unsur ketiga adalah kegiatan setelah pembacaan buku. Guru mengajukan pertanyaan "mengapa", "bagaimana", pertanyaan lanjutan serta memberikan model cara menanggapi.

Secara ringkas tingkat pengetahuan awal guru mitra terhadap strategi Read Aloud masih sangat kurang. Hal ini dapat dilihat dari ratarata capaian test pengetahun adalah 34 . Nilai ini jauh dari nilai ketuntasan yang diharapkan.

Kondisi demikan sinkron dengan pernyataan guru peserta yang menyatakan bahwa Read Aloud adalah setratagi pembelajaran baru dalam pembelajaran membaca. Selama ini mereka mengaku tidak mengikuti prosedur seperti yang digambarkan dalam kegiatan Read Aloud

Berdasar kondisi tersebut, kemudian kegiatan pemberikan materi Read Aloud dalam bentuk ceramah dan diskusi dilakukan. 


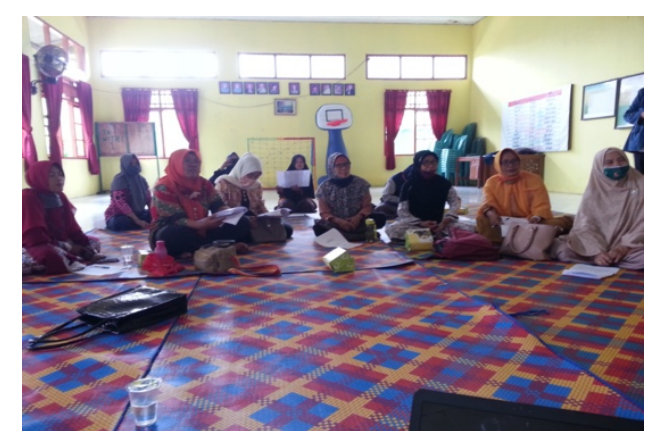

Gambar 1: Peserta Menyimak Presentasi Workhsop

Peserta mendapatkan makalah yang dapat dipakai untuk menambah wawasan pengetahuan tentang Read Aloud. Materi dalam makalah terdiri dari pengetahuan tentang pengertian Read Aloud, pentingnya Read Aloud dan tahapan pelaksanaan Read Aloud.

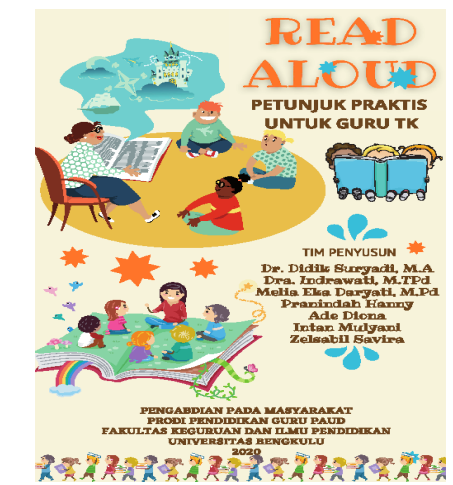

Gambar 2: Materi Workshop

Pendalaman materi dilakukan melalui kegiatan diskusi dan tanya jawab. Kegiatan ceramah dan diskusi materi Read Aloud, memberikan dampak signifikan pada pemahaman peserta terhadap strategi Read Aloud. Hal ini terlihat dari nilai capaian belajar para peserta. Tingkat penguasaan peserta terhadap materi berada pada kategori tuntas.

Seluruh peserta mencapi nilai ketuntasan di atas nilai yang diharapkan. Nilai rata-rata pengetahuan yang diperoleh dari 6 butir test pengetahuan adalah 84 .
Tabel 1: Nilai Pengetahuan Peserta

\begin{tabular}{|c|c|c|c|c|c|c|c|c|c|}
\hline & \multirow{2}{*}{ Peserta } & \multicolumn{9}{|c|}{ Skor Tlap Butir Pertanyaan } & \multirow{2}{*}{ Nilai } \\
\cline { 3 - 10 } & 1 & 2 & 3 & 4 & 5 & 6 & IML & \\
\hline 2 & DK & 9 & 8 & 9 & 9 & 8 & 9 & 52 & 87 \\
\hline 3 & BJ & 9 & 8 & 9 & 9 & 8 & 9 & 52 & 87 \\
\hline 4 & RS & 9 & 9 & 9 & 9 & 9 & 9 & 54 & 90 \\
\hline 5 & TS & 8 & 7 & 8 & 9 & 7 & 8 & 47 & 78 \\
\hline 6 & KD & 8 & 8 & 9 & 8 & 8 & 9 & 50 & 83 \\
\hline 7 & RM & 8 & 9 & 9 & 9 & 9 & 9 & 53 & 88 \\
\hline 8 & DL & 9 & 9 & 8 & 9 & 9 & 8 & 52 & 87 \\
\hline 9 & HM & 7 & 9 & 9 & 9 & 9 & 9 & 53 & 88 \\
\hline 10 & KK & 9 & 8 & 8 & 8 & 8 & 8 & 47 & 78 \\
\hline 11 & NS & 9 & 8 & 8 & 9 & 8 & 8 & 49 & 82 \\
\hline 12 & SU & 9 & 8 & 8 & 9 & 8 & 8 & 50 & 83 \\
\hline 13 & MT & 8 & 8 & 8 & 9 & 8 & 8 & 49 & 83 \\
\hline & \multicolumn{8}{|c|}{ RATA-RATA } \\
\hline
\end{tabular}

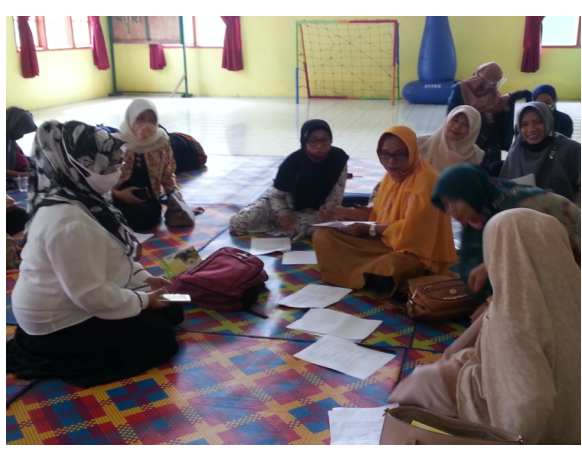

Gambar 3: Pendalaman Materi Workshop

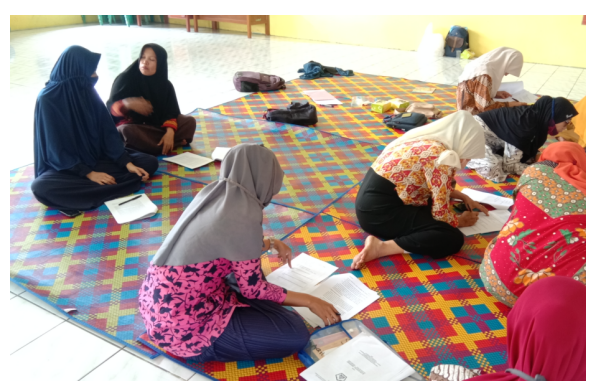

Gambar 4 : Aktivitas Workshop Peserta

Konsisten dengan hasil test pengetahuan awal para peserta, maka kegiatan praktek Read Aloud pada awalnya juga menunjukan hasil yang sangat kurang, jauh di bawah nilai ketuntasan yang diharapkan. Para peserta cenderung mendasarkan kebiasaan yang dilakukan ketika membacakan buku kepada anak. Pada umumnya mereka cenderung bercerita tentang buku. Buku dipakai sebagai landasan bercerita. Sehingga yang terjadi adalah bercerita. Kegiatan membaca buku kurang menjadi perhatian utama. Hampir seluruh peserta memulai pembacaan buku tanpa didahului oleh pengenalan terhadap buku. Para peserta pada umumnya menyebutkan judul buku. Unsur lain dalam pengenalan buku sepeti 
ilustrator, prediksi isi dan juga pengenalan ilustrasi sampul buku tidak dilakukan. Unsur lain dalam Read Aloud yaitu pembacaan dan diskusi pasca pembacaan juga belum dilakukan. Penguasaan paling rendah adalah pada unsur diskusi pasca pembecaan buku. Rata-rata nilai aspek ini adalah 38. Sedangkan penguasaan paling tinggi adalah pada aspek pengenalan buku. Nilai rata-rata pada aspek ini adalah 57. Nilai rata-rata pada aspek pembacaan buku adalah 56.

Intervensi untuk memperbaiki kondisi demikian dilaksanakan melalui kegiatan ceramah dan diskusi serta praktik peer teaching.

Pada kegiatan peer teaching, peserta praktik melaksanakan Read Aloud kepada temannya. Kegiatan ini ditindak lanjuti dengan diskusi refektif untuk memperbaiki bagian unjuk kerja yang masih belum optimal. Tampak para peserta sudah mulai memahami tahapan yang perlu dilalui ketika menerapkan strategi Read Aloud kepada murid-murid.

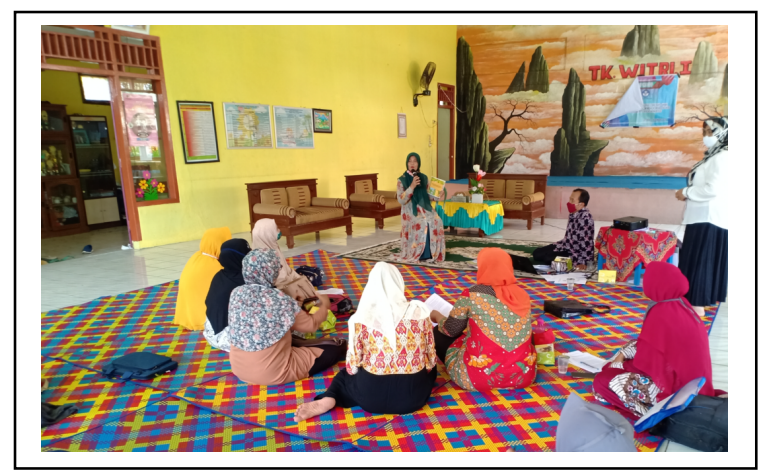

Gambar 5: Peserta praktek dalam peer teaching

Pemahaman terhadap langkah-langkah implementasi strategi Read Aloud kemudian dipraktikan di kelas nyata. Peserta memenerapkan strategi Read Aloud kepada anak-anak, yang diikuti dengan pengamatan oleh tim. Fokus pengamatan adalah implementasi langkah-langkah strategi Read Aloud kepada anak. Guru memilih dan membacakan buku bacaan untuk anak di depan kelas. Diberikan kesempatan kepada guru mitra untuk melakukan refleksi kegiatan praktik kelasa nyata dengan tim. Tampak anak-anak antusias ketika guru membacakan buku menggunakan strategi Read Aloud.

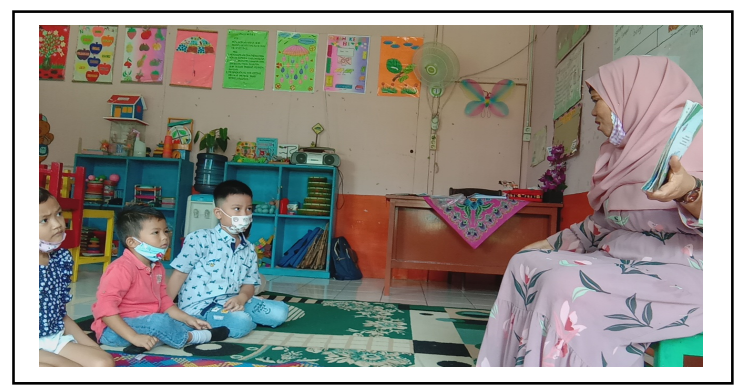

Gambar 6: Praktik di kelas nyata

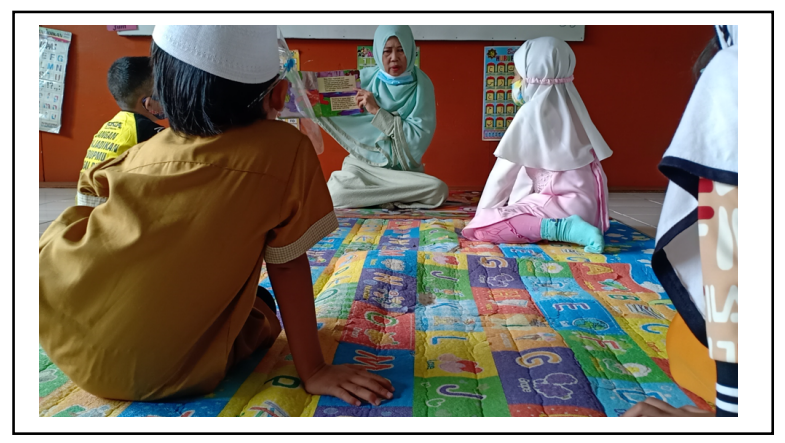

Gambar 7: Peserta praktik di kelas nyata

Hasil pengamatan menunjukkan terjadinya perubahan signifikan terhadap ketrampilan menerapkan strategi Read Aloud dari sebelum dan sesudah kegiatan peer teaching. Hal ini ditunjukkan oleh tingkat capaian unjuk kerja ketrampilan menerapkan strategi Read Aloud di kelas nyata. Tabel berikut menggambarkan tingkat capaian unjuk kerja ketrampilan para peserta dalam menerapkan strategi Read Aloud. Tabel 2 : Nilai Ketrampilan Peserta

\begin{tabular}{|c|c|c|c|c|c|}
\hline \multirow{2}{*}{ PESERTA } & \multicolumn{3}{|c|}{ ASPEK READ ALOUD } & \multirow{2}{*}{$\begin{array}{c}\text { NILAI } \\
\text { AKHIR }\end{array}$} \\
\cline { 3 - 5 } & $\begin{array}{c}\text { PENGENALAN } \\
\text { BUKU }\end{array}$ & PEMBACAAN & DISKUSI & AK \\
\hline 1 & DK & 93.8 & 85 & 68.8 & 82.69 \\
\hline 2 & BJ & 87.5 & 80 & 75 & 80.77 \\
\hline 3 & RS & 93.8 & 85 & 75 & 84.62 \\
\hline 4 & TS & 81.3 & 75 & 68.8 & 75.00 \\
\hline 5 & LD & 87.5 & 70 & 68.8 & 75.00 \\
\hline 6 & KM & 75 & 80 & 75 & 76.92 \\
\hline 7 & RM & 93.8 & 75 & 62.5 & 76.92 \\
\hline 8 & DL & 93.8 & 75 & 68.8 & 78.85 \\
\hline 9 & HM & 87.5 & 70 & 68.8 & 75.00 \\
\hline 10 & KK & 87.5 & 75 & 68.8 & 76.92 \\
\hline 11 & NS & 87.5 & 75 & 68.8 & 76.92 \\
\hline 12 & SU & 87.5 & 80 & 62.5 & 76.92 \\
\hline 13 & MT & 87.5 & 75 & 62.5 & 75.00 \\
\hline RATA-RATA & 88 & 76.9 & 68.8 & 77.81 \\
\hline
\end{tabular}

Terlihat dalam tabel 2 bahwa capaian unjuk ketrampilan para peserta dalam menerapkan sterategi Read Aloud telah mencapai tingkat ketuntasan yang diharapkan, yaitu $75 \%$ peserta menguasai $75 \%$ ketrampilan. Rata-rata capaian unjuk ketrampilan menerapkan strategi Read Aloud adalah $78 \%$. Capaian demikian menunjukkan bahwa para peserta telah memiliki potensi untuk menerapakan strategi Read Aloud dalam 
kelas mereka sebagai strategi mengembangkan kemampuan dan kemauan membaca anak. Kegiatan diskusi setelah membacakan buku tampaknya masih menjadi kendala bagi para guru. Hal demikian dapat dilihat dari nilai ratarata sebesar 69. Unsur kegiatan pasca membaca yang kurang ditampilkan oleh guru adalah memberikan model cara menanggapi. Cara menanggapi unsur cerita dengan menggunakan kata-kata "saya pikir", "menurut pendapat saya..." belum ditampilkan secara optimal oleh guru. Guru telah secara cukup baik megajukan pertanyaan dengan menggunakan kata tanya "mengapa..", "bagaimana..". Kata kata demikian menstimulasi anak untuk memberikan pendapatnya tentang unsur buku bacaan yang telah dibacakan oleh guru.

Secara umum, kegiatan ini secara nyata telah memerikan manfaat kepada para peserta. Para guru mitra telah memiliki pengetahuan dan ketrampilan untuk menerapkan strategi Read Aloud dalam pembelajaran membaca pada anak TK. Pengusaan pengetahuan dan ketrampilan menrapakan strategi pembelajaran oleh guru memberikan harapan terhadap dampak positif yang ditimbulkan pada aktivitas belajara anak. Hal ini sesuai dengan hasil penelitian Jupriyanto dan Nuridin yang menyatakan bahwa terdapat dampak siginigfikan penguasaan ketrampilan guru terhadap aktivitas belajar anak (Jupriyanto \& Nuridin, 2019)

Kemampuan guru menerapkan strategi Read Aloud juga dapat diharapkan meningkatkan kemampuan siswa memabahami bacaan. Hal ini sesuai dengan hasil penelitian Rokoyah yang menyimpulan bahwa terdapat pengaruh metode reading aloud terhadap pemahaman bacaan siswa kelas II MI (Rukoyah, 2014)

Anak-anak terlihat menyimak secara seksama ketika gurunya membacakan buku cerita kapada mereka. Mereka mengamati guru membuka halaman demi halaman, mereka mengamati bahwa deretan huruf yang membentuk kata dan kalimat dapat dibaca dan berisi sebuah cerita yang dapat dinikmati. Hal ini terlihat dari reaksi mereka yang sesekali berkomentar saat gurunya membacakan buku. Gejala demikian memberikan harapan tumbuh dan berkembangnya kemampuan pra literasi seperti penyadaran perbedaan adanya perbedaan bunyi yang melekat pada deretan huruf saat guru membacakan buku. Hal demikian merupakan dampak dari aktivitas membacakan buku kepada anak. Dampak dari aktivitas membaca seperti itu sesuai dengan hasil banyak penelitian (Duursma et al., 2008).
Para guru mitra tampak bersemangat memperaktekan strategi Read Aloud. Mereka merasa bahwa Read Aloud merupakan hal baru dan menarik. Hal demikian dapat dilihat dari hasil catatan lapangan yang merekam pembicaraan para guru dalam forum refleksi setelah kegiatan berlangsung. Pernyataan guru mitra seperti berikut : "baru tau saya bagaimana seharusnya membacakan buku untuk anak", "selama ini saya keliru karena saya tidak membacakan buku melainkan bercerita.. jadi tidak menstimulasi anak untuk membaca buku", "memang benar jika dilakukan seperti itu, anak anak bisa aktif, bisa kritis" adalah beberapa contoh yang dapat menunjukkan adanya motivasi dan juga pandangan positif guru terhadap strategi Read Aloud. Kepemilikian motivasi demikian dapat diharapkan akan berpengaruh terhadap prestasi belajar anak, seperti yang disimpulkan oleh (Badrus, 2018) dan (Nurmalina, 2019) bahwa motivasi guru berdampak positif terhadap prestasi belajar siswa

\section{KESIMPULAN \& SARAN}

Terdapat beberapa hal yang dapat disimpulkan dari pelaksanaan kegiatan pengabdian masyarakat ini. Pertama, rancangan dan pelaksanaan kegiatan ini berbasis pada landasan teoritis dan hasil penelitian tentang pentingnya penerapan strategi Read Aloud sebagai strategi pembelajaran membaca di TK. Kedua, timbulnya kesadaran pada guru mitra bahwa Read Aloud merupakan strategi baru bagi mereka, dan adanya perspektif positif tentang strategi Read Aloud serta timbulnya keiningan kuat untuk menerapkannya. Ketiga, pelaksanaan rancangan kegiatan yang terbagi menjadi 3 tahap pelaksanaan telah memberikan hasil berupa peningkatan pengetahuan dan kemampuan guru mitra menerapkan strategi Read Aloud. Dengan demikian, bila para guru mitra secara konsiten menerapkan strategi tersebut dalam pembelajaran di sekolah, maka dapat diharapkan akan menumbuhkan dan mengembangkan kemampuan dan kemauan membaca anak sejak usia dini. Disarankan sekolah mitra dan sekolah lainnya dapat mengimplementasikan strategi Read Aloud sebagai salah satu strategi pengembangan kemampuan dan kemampuan membaca sejak anak usia dini. 


\section{DAFTAR PUSTAKA}

Atmazaki, Ali, N. B. V., Muldian, W., Miftahussururi, Hanifah, N., Nento, M. N., \& Akbari, Q. S. (2017). Panduan Gerakan Literasi Nasional. Retrieved from

https://gln.kemdikbud.go.id/glnsite/wpcontent/uploads/2017/08/panduan-gln.pdf

Badrus, M. (2018). Pengaruh Motivasi Mengajar Guru Terhadap Prestasi Belajar Siswa Pada Mata Pelajaran Pendidikan Agama Islam: Studi di SMA Mardi Utomo Kecamatan Tarokan Kabupaten Kediri. Intelektual: Jurnal Pendidikan Dan Studi Keislaman, 8(2), 143-152. https://doi.org/10.33367/ji.v8i2.706

Duursma, E., Augustyn, M., \& Zuckerman, B. (2008). Reading aloud to children: The evidence. Archives of Disease in Childhood, 93(7), 554-557. https://doi.org/10.1136/adc.2006.106336

Harjanty, R. (2019). Peningkatan Kemampuan Membaca Permulaan melalui Membaca Nyaring (Penelitian Tindakan di Kelompok B RA Perwanida Praya, Lombok Tengah 2016). PAUD Lectura: Jurnal Pendidikan Anak Usia Dini, 3(1), 106-117. Retrieved from https://journal.unilak.ac.id/index.php/pau d-lectura/article/view/3353/1833

Hayat, B., \& Yusuf, S. (2015). Benchmark Internasional Mutu Pendidikan. Jakarta: Bumi Aksara.

Jupriyanto, \& Nuridin. (2019). Pengaruh Keterampilan Mengajar Guru Terhadap Aktivitas Belajar Siswa SD Negeri 04 Loning. Jurnal Pendidikan Dasar Indonesia, 4(1), 14-18. Retrieved from https://journal.stkipsingkawang.ac.id/inde x.php/JPDI/article/view/944

Kumar, K. K. (2015). Revitalizing the art of reading aloud to children. Retrieved from https://apiar.org.au/wpcontent/uploads/2016/01/ICTP_BRR717 EDU.pdf

Ledger, S., \& Merga, M. K. (2018). Reading aloud: Children's attitudes toward being read to at home and at school. Australian Journal of Teacher Education, 43(3), 124-139.

https://doi.org/10.14221/ajte.2018v43n3. 8

Mascareño, M., Deunk, M. I., Snow, C. E., \& Bosker, R. J. (2017). Read-alouds in kindergarten classrooms: a moment-bymoment approach to analyzing teacherchild interactions. European Early
Childhood Education Research Journal, 25(1), $136-152$. https://doi.org/10.1080/1350293X.2016.1 266226

McGee, L. M., \& Schickedanz, J. A. (2007). Repeated Interactive Read-Alouds in Preschool and Kindergarten. The Reading Teacher, 60(8), 742-751. https://doi.org/10.1598/rt.60.8.4

Morrow, L. M., Rand, M. K., \& Smith, J. K. (1995). Reading aloud to children: Characteristics and relationships between teachers and student behaviors. Reading Research and Instruction, 35(1), 85-101. https://doi.org/10.1080/19388079509558 199

Nurmalina. (2019). Pengaruh Motivasi Kerja Guru Terhadap Prestasi Belajar Siswa Pada SMP Negeri 2 Mesjid Raya. Journal of Education Science (JES), 5(1), 1-7.

Rahimah, F. Y., Rukayah, \& Hadiyah. (2014). Implementasi Metode Read Aloud Untuk Meningkatkan Kemampuan Bercerita Pada Anak Kelompok B Taman KanakKanak Nur Rahimah Banjarbaru Tahun Ajaran 2013/2014. Jurnal FKIP UNS, 2(4). Retrieved from https://jurnal.fkip.uns.ac.id/index.php/pau d/article/view/6856

Rukoyah, S. (2014). Pengaruh Metode Reading Aloud (Membaca Nyaring) Terhadap Pemahaman Bacaan Siswa Kelas II MI Nurul Huda Curug Wetan Tangerang Tahun Pelajaran 2013/2014 (Universitas Islam Negeri Syarif Hidayatullah). Retrieved from http://repository.uinjkt.ac.id/dspace/bitstr eam/123456789/24808/1/Siti Rukoyah.pdf

Sajid, M. K. M., Kassim, H., \& Hasan, G. A. (2019). Effectiveness of reading aloud strategies for developing reading habits. 163-181.

https://doi.org/10.5281/zenodo.3558794

Trelesase, J. (2017). The Read-Aloud Handbook Membacakan Buku dengan Nyaring, Melejitkan Kecerdsan Anak. Jakarta: Noura. 